\title{
Infant Irritability
}

National Cancer Institute

\section{Source}

National Cancer Institute. Infant Irritability. NCI Thesaurus. Code C117267.

Crying easily, difficult to console. 